\title{
Komparace postojů a názorů adolescentů ve věku 15-18 let ke sportu a pohybovým aktivitám
}

\section{Comparation attitudes and opinions of the adolescents at the age of 15-18 to the sport and movement activities}

\author{
Petr Jansa \\ Asociace školních sportovních klubů ČR
}

\begin{abstract}
Abstrakt
V článku předkládáme výsledky výzkumného šetření uskutečněného v roce 2015, které se zaměřovalo na zjištování názorů a postojů adolescentní mládeže (15-18let) k pohybovým aktivitám a sportu. Dílčí úkol spočival v komparaci těchto výsledků s výzkumem, který byl proveden v roce 2000 (Slepička et al., 2001), a to v kompatibilních položkách dotazníku PASA. Pracovní hypotéza předpokládala určité diference $v$ reálných odhadech vlastních sportovních a pohybových aktivit včetně výběru provozovaných sportů. Údaje byly zjištovány dotazníkem PASA (pohybové aktivity a sport adolescentů), který byl předložen adolescentům středních škol (gymnázii). Celkově bylo vyšetřeno 1067 respondentů, z toho bylo 468 chlapců a 599 dívek.

Z výsledků je zřejmé, že v roce 2000 více než $50 \%$ chlapců ve věku 15 až 18 let nedělá pohybově vůbec nic nebo jen stěží udržují existující kondici. V roce 2015 se skupina zmenšila na 40\%, nastalo tedy zlepšení o $10 \%$ ve prospěch pohybových aktivit a sportu u souboru chlapců. U dívek činily podily ve stejných letech $61 \%$ (2000) a $45 \%$ (2015), nastalo tedy překvapivé zlepšení ve prospěch pohybových aktivit a sportu o $16,1 \%$.

Po patnácti letech jsou výběry sportů u chlapců téměř shodné, preferují fotbal a cyklistiku, na třetím mistě byly v roce 2000 úpoly, a v roce 2015 běhání, jogging. Výsledky dívek se odlišují více, v roce 2000 byly prvními třemi sporty $v$ pořadí aerobik, volejbal a cyklistika, zatímco v roce 2015 beachvolejbal, posilování (domácí cvičení) a orientační běh.
\end{abstract}

\begin{abstract}
In the article we present the research results carried out in 2015. The research was focused on recognition of adolescents' opinions and attitudes (15-18 years of age) towards physical activities and sport from different points of view. A subtask dealt with comparing the research of compatible items resulting of the questionnaire PASA conducted in 2000 (Slepička et al., 2001). The work hypothesis assumed certain differences in the real estimates of own sporting and physical activities including the selection of practised sports. Data were analysed by the questionnaire PASA (physical activities and sport in adolescents), which was presented among adolescents at secondary schools (Grammar schools). In general, 1067 respondents were inquired, 468 of them boys and 599 girls.

Regarding the results it is clear that in 2000 more than $50 \%$ of boys aged 15 to 18 years of age did physically nothing at all or were just hardly keeping current physical condition. In 2015 only 40\%, which means improvement of about $10 \%$ in favor of physical activities and sports among boys. As for the girls it was over $61 \%$ (2000) and $45 \%$ (2015), and that was a surprising improvement in favor of physical activities and sports of $16,1 \%$.

Within the fifteen-year period, the selection of sports among boys, was almost identical. They preferred football and cycling. in the third place it was sightly different - in 2000, they preferred martial arts while in the year 2015 jogging. The girls differed more in the year 2000, the ranking was - aerobics, volleyball and cycling, but in 2015 - beach volleyball, work out (home exercise) and orienteering.
\end{abstract}


Klíčová slova: Postoje a názory, adolescenti, pohybové aktivity a sport, dotazník.

Keywords: Attitudes and opinions, adolescents, physical activity and sport, interview

\section{ÚVOD}

Článek podává informace učitelům tělesné výchovy na středních školách, trenérům nebo instruktorům, kteří se zabývají přípravou studentů v rámci mimoškolních sportovních aktivit. Ty organizuje například Asociace školních sportovních klubů České republiky. Ta zakládá a podporuje sportovní kluby na školách, kde se studenti dobrovolně účastní ve svém volném čase soutěží ve vybraných sportech. Pracovníci asociace vytvářejí organizační skupiny, které zodpovídají za koordinaci činností v regionech v podobě krajských a okresních rad včetně sekretariátu centra AŠSK ČR. Úzce spolupracuje s MŠMT, Českým olympijským výborem, Českou olympijskou akademií, aj.

Výzkumné šetření jsme zaměřili na komparaci názorů a postojů k pohybovým aktivitám a sportu u stř̌edoškolské mládeže na gymnáziích v různých sídlech v roce 2000 a 2015.

$\mathrm{Z}$ přehledu výzkumných šetření věnovaných této věkové skupině nejdříve uvádíme studii Saka (2000), který popisuje vývojové změny u české mládeže z hlediska sociálního časoprostoru a zrání, utváření hodnot a postojů, sociálních kompetencí, hodnotových preferencí a orientací, přehledu o využívání volného času u mládeže.

Zmíníme se o další studii Saka \& Sakové Mládež na křižovatce (2004), kde se provádí sociologická analýza postavení mládeže ve společnosti a jejích úloh v procesech europeizace a informatizace.

Výzkum se širším společenským významem uskutečnil Pelka (2002). Sledoval např. názory mládeže na současné a přiští působení mladé generace v EU, možnosti poznávání jiných zemí, na vztah mládeže $\mathrm{k}$ rodičům, rodině a starým lidem, na využíání volného času apod. V položce využití volného času byl též zařazen sport ve všech možných formách, ale bez určení pohlaví pravidelně o něj projevuje zájem $67 \%$ respondentů $(\mathrm{N}=928$ ve věku $15-24$ let).

Další šetření prováděl Rychtecký et al. (2006). Zaměřoval se na účast dospělé i mládežnické populace v pohybových a sportovních činnostech u nás. Metodika výzkumu byla identická s mezinárodním projektem Compass a umožňovala srovnání s některými zeměmi Evropské unie. Celkově bylo dotázáno u mládežnické kategorie 16-19 let přes 3000 osob. Z výsledků bylo zřejmé, že se mládež zúčastňuje pravidelných i nepravidelných sportovních a jiných pohybových aktivit od výkonnostní až po rekreační úroveň v $73 \%$.

Jinou zajímavou práci uvádí Fantová (2006), jejíž výzkumné šetření se zaměřovalo na zjištôvání názorů a postojů mládeže 15 -18leté na sport (chlapci $\mathrm{N}=497$ a dívek $\mathrm{N}=532$ ), tělesnou výchovu a jiné pohybové aktivity, na jejich psychosociální funkce v životním stylu, reálnou či pasivní účast v těchto aktivitách. Vyjadřuje se i k sociálně negativním projevům (agresivita, dopink, korupce apod.).

Autor diplomové práce Bártek (2009) zjištoval informace u adolescentní populace ve věku 15 až 18 let na gymnáziích, kdy se dotazoval na význam sportu a pohybových aktivit. Soubor celkem zahrnoval 570 dotazovaných, z toho 310 dívek a 260 chlapců z krajů Jihočeského a Vysočina. Dotazník byl členěn do několika oblastí a ptal se zejména na reálnou účast ve sportovních a pohybových aktivitách, které překážky brání těmto aktivitám, na patologické jevy v podobě dopingu a korupce, srovnával názory a postoje studentů gymnázií podle pohlaví. Autor konstatoval, že sport a pohybové aktivity jsou důležitou součásti životního stylu adolescentní mládeže ( 84 \%). Více jak $50 \%$ respondentů uvedlo, že sportu a pohybovým aktivitám věnují 10 a více hodin mě- 
síčně. Nejčastěji se věnují fotbalu, volejbalu a cyklistice, atd. Svoje aktivity rychle rozšiřují o nové sporty, a to zejména o snowboarding $(24,7 \%)$ a squash $(20,9 \%)$.

Zajímavou studii uvádí Kudláček, M., Kudláček, M., Kudláček, V. jr. \& Kudláček, V. (2010), kde byla analyzována struktura přeloženého dotazníku PSPP CZ (Physical Self Perception Profil profil tělesného sebevnímání) určeného pro populaci žáků středních škol. Profil (PSPP) nebyl nikdy předtím použit v ČR. Účastníky byli studenti středních škol, a to 666 chlapců a 403 dívek. Průměrný věk účastníků-chlapců byl 17 let, dívek 16,6 let. Testovací baterie zahrnovala českou verzi dotazníku PSPP, kde byly stanoveny čtyři parametry: (A) sportovní odborná způsobilost SPORT; (B) atraktivita postavy - TĚLO; (C) tělesná síla a svalstvo - SÍLA; (D) tělesná kondice a cvičení - STAV. Výsledky byly analyzovány pomocí ukazatele Cronbachova alfa, tím zjištěna vnitřní spolehlivost a obsah platnosti jen tří uvedených parametrů dotazníku vhodného pro českou populaci středoškoláků.

Kudláček \& James (2011) uvádějí výzkumné šetření, které bylo zaměřeno na zajištování intervenčního programu pro dospívající mládež v kategorii nadváhy/obezity v souladu s tělesnou aktivitou (PA) dle pokynů. Celková doba trvání projektu byla 8 týdnů. Cílem studie bylo posoudit účinky intervence s podporou celoživotní účasti na pohybových aktivitách. Soubor byl tvořen studenty středních škol $(\mathrm{n}=27)$, vybranými podle kritérii BMI mezi $25 \geq 35$,5. Data byla získána použitím dotazníků, internetu a krokoměrů, stejně jako objektivní měření výšky, tuku a BMI. Z výsledků je zřejmé, že nedošlo ke snížení BMI. Zvýšilo se množství pohybové aktivity a počty kroků v průběhu intervence, zaznamenali jsme čtyřikrát větší nárůst MET minut týdně. Zvýšená aktivita snižuje sedavý způsob života, který úzce souvisí s nadváhou.

Stat Novákové (Lokvencové), Skalika, Frömela \& Górna-Łukasika (2011) zjištovala, do jaké míry se liší školní den a víkend z hlediska tělesné aktivity v české, polské a slovenské populaci chlapců a dívek s různými kulturními a školními podmínkami. Do výzkumu byli zahrnuti respondenti v České republice ( $n=383$ účastníků), v Polsku ( $n=327$ účastníků) a na Slovensku v regionu Prešov ( 8 škol, 252 účastníků). Celkem 421 chlapců a 541 dívek se podílelo na studii. Účastníci měli krokoměry po dobu sedmi dní, zaznamenané hodnoty se prezentovaly v systému Indares. Soubory chlapců a dívek vykazovaly podstatně vyšší počet kroků ve dnech školního vyučování než o víkendu.

Sigmundová, El Ansari, Sigmund, \& Fromel (2011) konstatovali optimální úroveň pohybových aktivit v dospívání, která ovlivňuje stupeň pohybových aktivit v dospělosti. Studie hodnotila úroveň, typy a sekulární trendy pohybových aktivit a sedavý způsob chování na vzorku adolescentů v České republice. Jednalo se o dva soubory dospívajících vzdálených od sebe deset let. Šlo celkem o 902 osob ( $\mathrm{N}=410$ chlapců a $\mathrm{N}=492$ dívek $)$ ve věku 14-18 let. Údaje se získávaly v týdenním sledování pohybových aktivit krokoměry v letech 1998-2000 a 2008-2010. Z výsledků je zřejmé, že nadváha a obezita se u českých adolescentů zvýšila za deset roků z 5,5\% na 10,4\%. U dívek došlo ve všední dny k výraznému zvýšení celkové délky sedavého chování mladšího souboru oproti starším výsledkům, především u televize a počítače. Hlavním kritériem podpory zdraví bylo dosažení 11000 kroků za den. Hodnota byla snížena pouze u chlapců z 68 \% (1998-2000) na $55 \%$ (2008-2010), přitom každý desátý adolescent vykazoval nadváhu nebo obezitu. Celkově bylo zjištěno, že až tři čtvrtiny dospívajících nenaplňují kritérium dostatečného počtu krokủ podporujícího zdraví.

Zajímavou diplomovou práci uvádí Hájek (2011), který adolescentní období považuje za rizikové z důvodu snižování pohybových aktivit obecně. Dotazníkovým šetřením vyjadřuje nejdůležitější charakteristiky habituálních pohybových aktivit studentů střední školy, analyzuje jejich skladbu a úroveň, posuzuje charakter pohybového zatížení s přihlédnutím k vybraným faktorům, které mohou pohybovou aktivitu ovlivňovat. Ke sbírání údajů byla využita standardizovaná verze Mezinárodního dotazníku o pohybových aktivitách (IPAQ-short). Soubor tvořilo 215 studentů. 
Z výsledků vyplynulo, že chlapci v porovnání s dívkami vykazovali značné rozdíly zejména v účasti na organizovaných formách pohybových aktivit. Místo bydliště se projevuje jako signifikantní faktor. Polovina zkoumaného vzorku vykazuje vysokou pohybovou aktivitu. Na základě zjištěných výsledků lze sestavit programy ke zvýšení pohybové aktivity adolescentů.

Gába, Chmelík, Jakubec, \& Botek (2012) uváději studii, v níž analyzovali složení těla a tělesnou aktivitu dospívajících žen $(\mathrm{N}=51)$ s průměrným věkem 15,8 let. Např. zjištované BMI měly ženy v $80 \%$ v rozmezí normálu, $18 \%$ mělo nadváhu a jedna žena byla obézní. Výsledky ukázaly, že dospívající ženy mají nízkou úroveň pohybových aktivit o víkendech. Autoři doporučují primární prevenci obezity zvýšením pohybových aktivit ve volném čase, zejména o víkendech.

Další studii uvádí Boyer, Nelson, Sheyla \& Holub (2015), kteří sledovali trajektorii růstových parametrů chlapců a dívek vyjádřených BMI. Ty byly vyhodnoceny kvadratickou růstovou křivkou jako možnosti kardiovaskulárního onemocnění (CVD), rizika v dospívání. Porovnáním parametrů v rámci pohlaví konstatovány jako index rizika ve věku 15 let. Chlapci měli extrémnější trajektorie rizika vzniku IChS než dívky.

Významné jsou i publikace autorů Armoura (2011) a Tinniga (2010), ale i články v časopisech Journal of Adolescent Health and Health Education Journal.

V rámci výzkumné zprávy Společenské reflexe sportu (Slepička et al., 2001) se provádělo samostatné šetření zaměřené na adolescentní mládež. Soubor tehdy zahrnoval skupinu 15-18letých $(\mathrm{N}=805)$, získané výsledky nebyly zveřejněné. Autor statě využil databázi z roku 2000 pro srovnávání s kompatibilními položkami upraveného dotazníku v roce 2015.

Podle uvedeného přehledu jsme stanovili záměr výzkumného šetření, který spočíval ve zjištování postojů a názorů 15-18leté adolescentní mládeže na sport a pohybové aktivity na středních školách z různých hledisek v roce 2015. Dílčí cíl spočíval v komparaci těchto výsledků s výzkumem, který byl proveden $\mathrm{v}$ roce 2000 (Slepička et al., 2001) v kompatibilních položkách dotazníku PASA.

Pozornost věnujeme komparacím mezi soubory chlapců a dívek $\mathrm{v}$ adolescentním věku, kdy jsme předpokládali určité diference $v$ reálných odhadech vlastních sportovních a pohybových aktivit včetně výběru provozovaných sportů.

\section{METODIKA}

\section{Dotaznik PASA (Pohybové aktivity a sport adolescentů)}

Dotazník PASA byl upraven podle Dotazníku pro 15-18leté adolescenty užívaného v roce 2000. Původní dotazník obsahoval celkem 53 otázek se 168 variantami odpovědí. Dotazník jsme upravili do 25 kompatibilních otázek s původní verzí, pilotáž se prováděla na vzorku 35 adolescentů v roce 2015. Jednotlivé oblasti dotazníku zahrnovaly: identifikační údaje včetně tělesné výšky a hmotnosti; názory a postoje na současnou roli pohybových aktivit a sportu v životě adolescentů; reálné odhady vlastních pohybových a sportovních aktivit vyjádřené měsíční frekvencí, účasti v soutěžích, úrovní, apod.; využivání tělovýchovných a sportovních zařízení; preference pohybových aktivit a sportů; finanční podporu těmto aktivitám; domácí vybavení náčiním či nářadím, atd.

Dotazník PASA byl předkládán adolescentům ze středních škol-gymnázií na základě dvoustupňově stratifikovaného výběru (kraj, okres, obvod, město) ve věku 15 až 18 let v roce 2015. Do šetření bylo vybráno celkem šest gymnázií z Prahy a z pěti mimopražských měst (15-25 tis. obyvatel). 
Tab. 1: Charakteristika souboru adolescentů 15-18 let

\begin{tabular}{|c|c|c|c|c|}
\hline Pohlaví & & $\mathbf{N}$ & $\mathbf{\%}$ & Celkově \\
\hline Chlapci & $15-16$ let & 157 & 33,5 & 33,5 \\
\cline { 2 - 5 } & $17-18$ let & 311 & 66,5 & 66,5 \\
\cline { 2 - 5 } & Celkově & 468 & 100,0 & 100,0 \\
\hline \multirow{4}{*}{ Dívky } & $15-16$ let & 182 & 30,4 & 30,4 \\
\cline { 2 - 5 } & $17-18$ let & 417 & 69,6 & 69,6 \\
\cline { 2 - 5 } & Celkově & 599 & 100,0 & 100,0 \\
\cline { 2 - 5 } & & $\mathbf{N}$ & $\mathbf{\%}$ & Celkově \\
\cline { 2 - 5 } & Praha & 551 & 51,6 & 51,6 \\
\cline { 2 - 5 } & Ostatní & 516 & 48,4 & 48,4 \\
\cline { 2 - 5 } & Celkově & 1067 & 100,0 & 100,0 \\
\hline
\end{tabular}

\section{Charakteristika souboru}

Dotazovaný soubor ukazuje tabulka č. 1. Celkově se jedná o 1067 dotázaných, z toho bylo 468 chlapců a 599 dívek. Soubor byl rozdělen pro výzkumnou zprávu na skupiny zahrnující dvouleté věkové rozpětí. Věková kategorie 15 a 16letých čía 157 chlapců a 182 dívek, u 17 a 18letých 311 chlapců a 417 dívek. Statistické zpracování se provádělo v programech Excel a SPSS. Výsledky uvádíme jen v celkovém rozlišení dle pohlaví, mezi soubory vyjadřujeme statistickou významnost pomocí $\chi$ (stupeň diferenciace, vypočtenou hodnotu a pravděpodobnost přijetí hypotézy).

\section{VÝSLEDKY}

Skutečné odhady pohybových a sportovních aktivit adolescentních respondentů uvádíme v obrázku č. 1. Podle počtu odcvičených hodin můžeme uvažovat o udržovacím nebo rozvíjejícím programu z hlediska tělesné zdatnosti či kondice. Pro naše šetření jsme určili stupně pohybových a sportovních aktivit z hlediska frekvence zatěžování (cca 30 min. střední intenzity nebo $2 \mathrm{~km}$ rychlejší chůzí), které se hodnotí v měsíčním režimu následovně, upraveno podle Slepičky et al.(2001):

1. pásmo - 0 hod. - žádné pohybové aktivity (žádné tělesné zatěžování), nedostačující,

2. pásmo - 1 až $10 \times$ - pohybové aktivity nízké, tělesné zatížení nízké, i při vyšší intenzitě cvičení jen obtížně udržuje tělesnou kondici,

3. pásmo - 11 až $20 \times$ - pohybové aktivity a sport se středním zatížením, může udržet nebo rozvíjet tělesnou kondici,

4. pásmo - 21× a vícekrát - pohybové aktivity a sport s vyšším zatížením, které mohou rozvíjet tělesnou kondici, ve sportu pak sportovní výkonnost.

Obrázek č. 1 znázorňuje měsíční frekvence chlapců souhrnně, kde v prvních sloupcích je rozdíl víc než $7 \%$ ve prospěch souboru z roku 2000, frekvence se zjevně přesouvají do předposledních a posledních sloupců s frekvencemi prováděnými 11 až 20 a vícekrát, v obou případech vyšší než 5 \%, signifikantně. Ukazuje se, že téměř polovina chlapců (49,6 \%) z r. 2000, tak i z r. 2015 (59,1 \%) provozuje celkem pravidelné sportovní a pohybové aktivity, které udržují nebo rozvíjejí jejich tělesnou kondici nebo sportovní výkonnost, tj. frekvence vyšší než 21 krát měsičně, srov. Jansa (2015). 


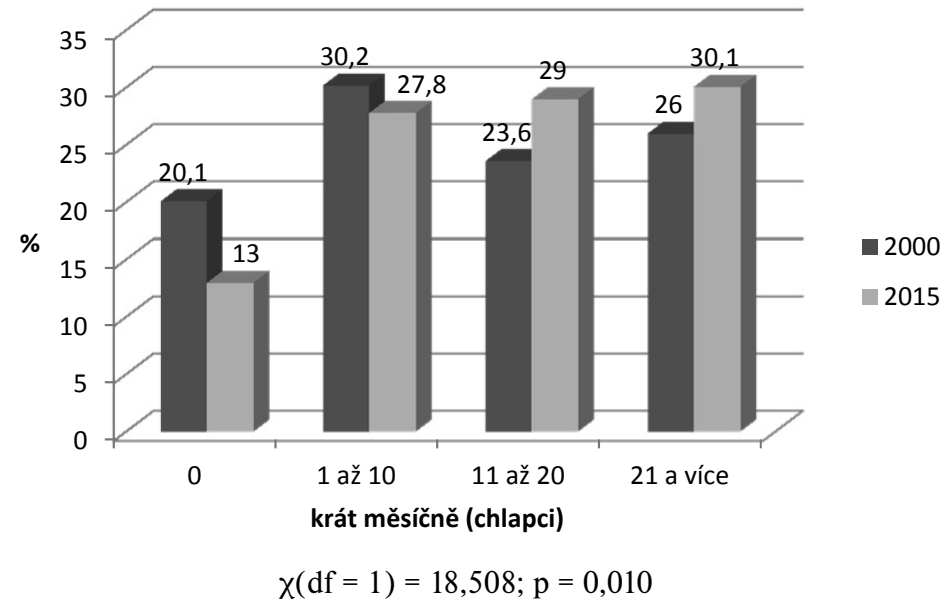

Obr. 1: Srovnání měsíčních frekvencí sportovních a pohybových aktivit u chlapců v letech 2000 $(\mathrm{N}=407)$ a $2015(\mathrm{~N}=468)$.

U dívek (obr. č. 2) jsou tyto tendence razantnější, v prvním sloupci „Žádné aktivity“ uvádí jen $7 \%$ v roce 2015 oproti 2000 , kde je uváděna hodnota $25,9 \%$, tj. rozdíl $18,9 \%$ signifikantně v neprospěch souboru z roku 2015. Zvýšení frekvencí je podobné jako u chlapců, tedy jsou udržující nebo rozvijející tělesnou zdatnost či kondici.

Změny, které se objevují s vyššími frekvencemi sportovních a pohybových aktivit v roce 2015 u dívek ve třetím sloupci (o 9,4 \%), o 7,2\% ve čtvrtém sloupci, též signifikantně, zde předpokládáme provozování výkonnostního sportu. Zřejmě se zde promítají vlivy společenské a ekonomické za zhruba 15leté období. Tendence je poměrně překvapivá u dívek, které se spíše vyhýbají pohybovým aktivitám a sportu. Podrobněji rozvádí např. Jansa (2015). Tabulka č. 2 a, b uvádí odpovědi na otázku Jsou sport a ostatní pohybové aktivity významné ve volném čase? U souboru chlapců 15 až 18letých v r. 2000 konstatujeme nejvyšší hodnoty ve sloupci „stř́edni“ 46,5\%, v r. 2015 pak $43,3 \%$, v tab. č. 2 b dívky 50,6 \% a 51,8 \%. Ostatní sloupce v hodnocení „velký“ mají chlapci 26,9\% v roce 2000 , o něco méně $24,4 \%$ v roce 2015 . Dívky pak „velký“ jen $16,9 \%$.

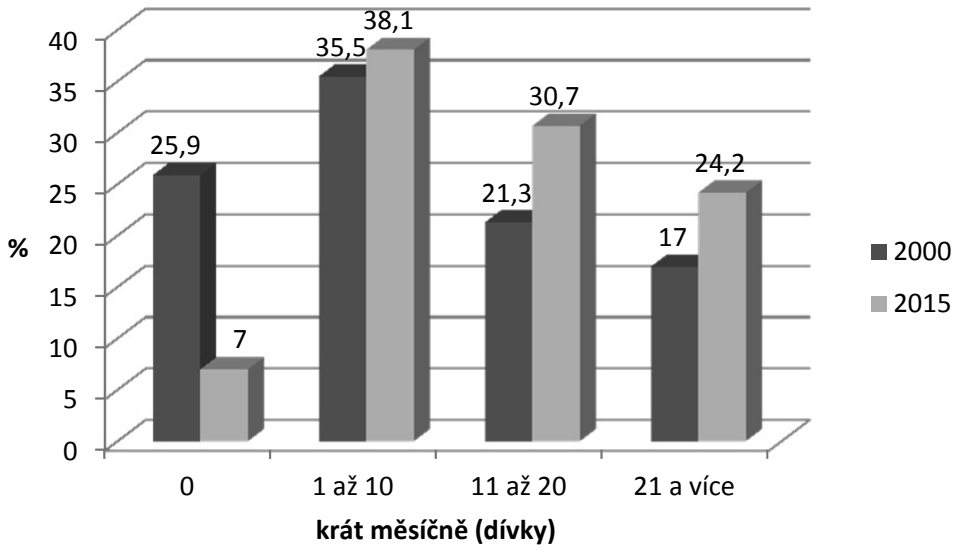

$\chi(\mathrm{df}=1)=73,195 ; \mathrm{p}=0,001$

Obr. 2: Srovnání měsíčních frekvencí sportovních a pohybových aktivit u dívek v letech 2000 (N=394) a $2015(N=599)$ celkově. 
Tab. 2a: Jsou sport, tělesná výchova a pohybové aktivity významné pro využití volného času? (chlapci 15 až 18 let)

\begin{tabular}{|c|c|c|c|c|c|c|c|}
\hline \multirow{2}{*}{\multicolumn{3}{|c|}{ Chlapci }} & \multicolumn{4}{|c|}{ @2d } & \multirow{2}{*}{ Celkově } \\
\hline & & & velký & střední & malý & žádný & \\
\hline \multirow{4}{*}{ Soubory } & \multirow{2}{*}{2000} & $\mathrm{~N}$ & 107 & 185 & 90 & 16 & 398 \\
\hline & & $\%$ & $26,9 \%$ & $46,5 \%$ & $22,6 \%$ & $4,0 \%$ & $100,0 \%$ \\
\hline & \multirow{2}{*}{2015} & $\mathrm{~N}$ & 114 & 202 & 108 & 43 & 467 \\
\hline & & $\%$ & $24,4 \%$ & $43,3 \%$ & $23,1 \%$ & $9,2 \%$ & $100,0 \%$ \\
\hline
\end{tabular}

$\chi(\mathrm{df}=3)=9,519 ; \mathrm{p}=0,023$

Prokázaná statistická významnost rozdílů mezi soubory je patrná u chlapců, z věcného hlediska nepatrně ve prospěch souboru z roku 2000. U dívek je tomu obráceně, ve prospěch dívek z roku 2015.

Tab. 2b: Jsou sport, tělesná výchova a pohybové aktivity významné pro využití volného času? (dívky 15-18 let)

\begin{tabular}{|c|c|c|c|c|c|c|c|}
\hline \multicolumn{2}{|c|}{} & \multicolumn{5}{c|}{ @2d } & \multirow{2}{*}{ Celkov̌ } \\
\cline { 4 - 8 } & \multirow{2}{*}{2000} & $\mathrm{~N}$ & 91 & 196 & 83 & 17 & 387 \\
\cline { 3 - 8 } & \multirow{3}{*}{ Soubory } & $\%$ & $23,5 \%$ & $50,6 \%$ & $21,4 \%$ & $4,4 \%$ & $100,0 \%$ \\
\cline { 2 - 8 } & \multirow{2}{*}{2015} & $\mathrm{~N}$ & 101 & 310 & 145 & 43 & 599 \\
\cline { 3 - 8 } & & $\%$ & $16,9 \%$ & $51,8 \%$ & $24,2 \%$ & $7,2 \%$ & $100,0 \%$ \\
\hline
\end{tabular}

$\chi(\mathrm{df}=3)=9,173 ; \mathrm{p}=0,027$

V tabulkách č. 3a,b jsou uvedena pořadí sportů a pohybových aktivit, které respondenti preferovali podle předloženého seznamu z celkové nabídky 89 položek. V tabulce uvádíme jen prvních sedm pohybových aktivit a sportů. U chlapců je roku 2000 nejvíce četný fotbal (26,7 \%), následuje cyklistika nebo horská kola (8,6\%), úpolové sporty $(5,4 \%)$, atletika (5,1\%), dále pak lední hokej 4,6 \%, orientační běh a stolní tenis. Ostatní činnosti mají nižší procentuální hodnotu a dále je neuvádíme. V roce 2015 jsou první dvě aktivity shodné - fotbal $(18,8 \%)$, cyklistika (13,3\%), běhání $(9,8 \%)$, posilování $(8,7 \%)$, orientační běh $(8,1 \%)$, baseball $(6,4 \%)$, pokračuje sjezdové lyžování, in-line bruslení (hokej), atletika a stolní tenis.

Zajímavé je, že do seznamu pohybových aktivit byly zařazeny např. procházky se psem, rodinné vycházky, práce na zahrádce, houbaření či uklízení, které však adolescenti téměř nevybírali.

Tab. 3a: Pořadí sportů a pohybových aktivit u adolescentních chlapců v roce 2000 (N = 407)

\begin{tabular}{|c|c|c|c|c|}
\hline Pořadí & označ. & četnost & $\%$ & aktivity \\
\hline 1 & 17 & 109 & $26,78 \%$ & fotbal \\
\hline 2 & 28 & 35 & $8,60 \%$ & cyklistika \\
\hline 3 & 7 & 22 & $5,41 \%$ & úpol. sporty \\
\hline 4 & 27 & 21 & $5,16 \%$ & atletika \\
\hline 5 & 11 & 19 & $4,67 \%$ & lední hokej \\
\hline 6 & 82 & 19 & $4,67 \%$ & orientační běh \\
\hline 7 & 48 & 17 & $4,18 \%$ & stolní tenis \\
\hline
\end{tabular}


$\mathrm{Z}$ tabulek je patrné, že chlapci v obou souborech preferují fotbal na prvním místě a cyklistiku, horská kola na druhém. Dále nalézáme shodné aktivity, i když v jiném pořadí, nejblíže orientační běh, hokej a atletika.

Tab. 3b: Pořadí sportů a pohybových aktivit u adolescentních chlapců v roce 2015 ( $N=468)$

\begin{tabular}{|c|c|c|c|c|}
\hline pořadí & sport & četnost & \multicolumn{1}{c|}{$\%$} & aktivity \\
\hline 1 & 17 & 88 & $18,80 \%$ & fotbal \\
\hline 2 & 28 & 61 & $13,03 \%$ & cyklistika \\
\hline 3 & 23 & 46 & $9,83 \%$ & běhání, jogging \\
\hline 4 & 19 & 41 & $8,76 \%$ & posilování, dom. cvičení \\
\hline 5 & 82 & 38 & $8,12 \%$ & orientační běh \\
\hline 6 & 7 & 37 & $7,91 \%$ & baseball, softbal \\
\hline 7 & 2 & 30 & $6,41 \%$ & sjezdové lyžování \\
\hline
\end{tabular}

Dívky v tab. č. 3a, b z roku 2000 preferují aerobik (20\%), volejbal 12,9\% a cyklistiku, horská kola $9,1 \%$, ostatní sportovní a pohybové aktivity jsou méně četné, a to v pořadí: plavání $(6,8 \%)$, posilování (domácí cvičení), úpol. sporty, sjezdové lyžování, beachvolejbal, orientační běh a tanec. V roce 2015 se na první místo dostává beachvolejbal (23,5\%), dále posilování (domácí cvičení $13,7 \%)$ a orientační běh $10,4 \%$ - srov. Jansa (2015).

Velmi překvapivé je nezařazení aerobiku v roce 2015, který není tak populární jako současné nové formy cvičení např. Pilates, zumba, P-class, kickbox, trampolíny, dance aerobic aj., které jsou více přijatelné pro adolescentní dívky. Na čtvrtém místě se objevuje cyklistika, která v roce 2000 byla třetí, na pátém pak volejbal, šestém plavání atd.

Tab. 4a: Pořadí sportů a pohybových aktivit u adolescentních dívek v roce 2000 ( $N=394)$

\begin{tabular}{|c|c|c|c|c|}
\hline pořadí & sport & četnost & \multicolumn{1}{c|}{$\%$} & aktivity \\
\hline 1 & 1 & 79 & $20,05 \%$ & aerobik \\
\hline 2 & 51 & 51 & $12,94 \%$ & volejbal \\
\hline 3 & 28 & 36 & $9,14 \%$ & cyklistika \\
\hline 4 & 37 & 27 & $6,85 \%$ & plavání \\
\hline 5 & 19 & 24 & $6,09 \%$ & posilování, dom. cvičení \\
\hline 6 & 7 & 22 & $5,58 \%$ & úpol. sporty \\
\hline 7 & 2 & 21 & $5,33 \%$ & sjezdové lyžování \\
\hline
\end{tabular}

Je celkem logické, že nové populární sporty nebo pohybové aktivity se tlačí do popředí. Zajímavý je posun orientační běhu z devátého místa v roce 2000 na čtvrté v roce 2015, srov. Jansa (2015). Podobně beachvolejbal, který se prosadil jednoznačně na první místo v roce 2015, ale v roce 2000 se téměř nevyskytuje. 
Tab. 4b: Pořadí sportů a pohybových aktivit u adolescentních dívek v roce 2015 ( $\mathrm{N}=599)$

\begin{tabular}{|c|c|c|c|c|}
\hline pořadí & označ. & četnost & \% & aktivity \\
\hline 1 & 23 & 141 & $23,54 \%$ & beachvolejbal \\
\hline 2 & 19 & 82 & $13,69 \%$ & posilování, dom. cvičení \\
\hline 3 & 82 & 62 & $10,35 \%$ & orientační běh \\
\hline 4 & 28 & 51 & $8,51 \%$ & cyklistika, \\
\hline 5 & 51 & 49 & $8,18 \%$ & volejbal \\
\hline 6 & 37 & 48 & $8,01 \%$ & plavání \\
\hline 7 & 52 & 43 & $7,18 \%$ & tanec klasický \\
\hline
\end{tabular}

\section{DISKUSE}

Volný čas adolescentů je zajímavé téma $\mathrm{k}$ diskusi. V roce 2000 se ukazuje, že více než $50 \%$ a v roce $201540 \%$ chlapců ve věku 15 až 18 let nedělá pohybově vůbec nic nebo jen stěží udržují existující kondici, u dívek ve stejném pořadí přes $61 \%$ a $45 \%$. Přesto můžeme konstatovat, že k určitému zlepšení v roce 2015 dochází překvapivě u dívek.

Za hlavní prríčiny neúplného zájmu o pohybové a sportovní aktivity spatřujeme explozi informačních technologií, které ovlivňují zájmové činnosti ve volném čase adolescentů, např. televize, mobilní telefony, tablety, počítače a s nimi spojené počítačové hry, internet, digitální foto, internetové nákupy, atd.

Objevují se i nové sporty, o které má současná adolescentní generace zájem, např. bungee jumping, parkour, skateboard, snowboard, snowkiting, freeride, freestyle) nebo nabídka wellnes či fitness center. Mění se formy aerobiku (classic, step, dance, atd.), posilování (overball, kalanetika, crossfit, power joga, spinning). Velké oblibě se těší squash, ricochet nebo zejména mezi mládeží expandující florbal, ale také nabídka různých bojových sportů (např. aikido, kendo, kung-fu, taiči). Existují i další zájmové možnosti, např. školní kroužky dramatické, hudební, výtvarné aj.

Cyklistiku a in-line bruslení oproti roku 2000 podporují nové cyklostezky, pravidelný rekreační sport mimo soutěže (vlastní financování sportovních zařízení), posilovny v přírodě, apod.

\section{ZÁVĚRY}

Srovnání měsíčních frekvencí sportovních a pohybových aktivit u chlapců ukazuje, že více než polovina souboru provozuje celkem pravidelné sportovní a pohybové aktivity, které udržují nebo rozvíjejí jejich tělesnou kondici frekvence 10-20krát měsíčně, popř. sportovní výkonnost s frekvencí vyšší než 21 krát měsičně, a to o $5 \%$ ve prospěch roku 2015. Podobně se i u dívek zvyšují frekvence (11-20krát) měsíčních pohybových aktivit o $9,4 \%$ a frekvence 21 krát a více o 7,2\%. Změny, které se objevují s vyššími frekvencemi sportovních a pohybových aktivit v roce 2015 u chlapců i dívek, mají zřejmě př́činy ve změnách společenských, ekonomických, nebo vlastního „body image“. Tato tendence je poměrně překvapivá u dívek, zejména $\mathrm{z}$ hlediska předpokládané pasivity. Můžeme odpovědět i na hypotézu, že adolescentní mládež v roce 2015 vykazuje z hlediska věcné významnosti o něco vyšší zájem o pohybové a sportovní aktivity než soubory v roce 2000.

Preference sportovních a pohybových aktivit je za patnáctileté období u chlapců téměř shodná, vybírají si fotbal a cyklistiku, na třetím místě jsou v roce 2000 úpoly, v roce 2015 běhání, jogging. Dívky se odlišují více, v roce 2000 mají první tři pořadí aerobik, volejbal a cyklistika, a v roce 2015 beachvolejbal, posilování (domácí cvičení) a orientační běh. 


\section{Literatura}

Armour, K. et al. (2011). Sport pedagogy. London: Pearson.

Bártek, M. (2009). Aktivní životní styl adolescentní mládeže (Diplomová práce). Praha: UK FTVS.

Boyer, B. P., Nelson, J. A., Shayla C. \& Holub, S. C. (2015). Childhood Body Mass Index Trajectories Predicting Cardiovascular Risk in Adolescence. Journal of Adolescent Health, 2015. Vol. 56 Iss. 4, P. 536-540

Fantová, P. (2006). Názory (postoje) mládeže na sport, tělesnou výchovu a jiné pohybové aktivity v rámci životního stylu (Diplomová práce). Ústí nad Labem: UJEP PF.

Hájek, J. (2011). Analýza pohybové aktivity studentů střední školy ve vybraném regionu (Diplomová práce). Olomouc: UP FTK. Jansa, P. (2015). Postoje a názory adolescentů ve věku 15-18 let ke sportu a pohybovým aktivitám (Diplomová práce). Praha: UK FTVS.

Kudláček, M., Kudláček, M., Kudláček, V. jr. \& Kudláček, V. (2010). Components/factors of the Czech version of the Physical Self Perception Profile (PSPP-CZ) among high school students. Acta Universitatis Palackianae Olomucensis. Gymnica, 40(4), s. 25-31.

Kudláček, M., \& James, L. (2011). Effects of a school-based intervention program for adolescents with a special focus on the overweight/obese population. Acta Universitatis Palackianae Olomucensis. Gymnica, 41(2), 17-26.

Nováková (Lokvencová), P., Skalik, K., Frömel, K., \& Górna-Łukasik, K. (2011). An analysis of school physical activity in adolescent girls. Acta Universitatis Palackianae Olomucensis. Gymnica, 41(2), 65-70.

Pelka, F. (2002). Eurobarometr České republiky 2002. Praha: DM MŠMT.

Rychtecký, A. et al. (2006). Monitorování účasti mládeže ve sportu a pohybové aktivitě. Praha: UK FTVS.

Sak, P (2000). Proměny české mládeže. Praha: Petrklíč.

Sak, P. \& Saková, K. (2004). Mládež na křižovatce. Praha: Svoboda servis.

Sigmundova, D., El Ansari, W., Sigmund, E., \& Frömel, K. (2011). Secular trends: A ten-year comparison of the amount and type of physical activity and inactivity of random samples of adolescents in the Czech Republic. BMC Public Health, 11(1), 731. Slepička, P. et al. (2001). Společenská reflexe sportu. Výzkumný grant MŠMT. Praha: UK FTVS.

Tinning, R. (2010). Pedagogy and Humen Movement. London. 